\title{
Maximum Pressure, Minimum Deal: President Trump's Trade War with a Rising China*
}

\author{
Holger Janusch and Daniel Lorberg
}

\begin{abstract}
In the context of the American decline, President Trump's trade war toward a rising China fits into the pattern of a declining hegemon, as predicted by hegemonic stability theory. Trump's trade policy is driven by his view of trade as a zero-sum game, his fixation on the trade deficit, and his "maximum pressure" negotiation approach. The result - the "phase one" deal - seems to be a trade ceasefire rather than a lasting trade peace between the declining hegemon and its ascending challenger because it stands on a shaky foundation. This "phase one" deal does not address the structural problems in the US-Sino trade relation. Moreover, its goals are unrealistic, and it is built upon a dispute settlement that favors deal determination over rule-based conflict resolution.
\end{abstract}

Keywords: US trade policy, trade war, China, hegemony, international negotiation

Schlagwörter: US-Handelspolitik, Handelskrieg, China, Hegemonie, internationale Verhandlungen

\section{Introduction}

1 new sheriff is in town. From the beginning of his presidency, Donald Trump has been shaking up world trade politics. One of his first official acts as president was to order the withdrawal of the US from the Trans-Pacific Partnership (TPP). He threatened several countries and companies, including American producers, with the imposition of tariffs. The Trump administration blocked the appointment of judges to the panel that hears appeals in trade disputes and thereby crippled the dispute settlement of the World Trade Organization (WTO). However, its boldest move was starting a trade war with China.

In January 2018, the Trump administration imposed safeguard tariffs on Chinese imports, such as solar panels and washing machines, worth $\$ 10$ billion. In March of the same year, the United States levied tariffs on many trading partners - 25 percent on steel and 10 percent on aluminum - arguing the measure served US national security. The tariffs included Chinese imports worth $\$ 2.8$ billion. In return, China imposed retaliatory tariffs on US imports worth $\$ 2.4$ billion. In June, the conflict intensified when the Trump administration raised a 25 percent US tariff on Chinese imports worth $\$ 34$ billion due to unfair trade practices, such as intellectual property theft. This action was followed by additional tariffs on Chinese imports worth $\$ 16$ billion in August. In both cases, China immediately retaliated with tariffs of the same amount. The trade dispute increasingly developed into a spiral of tariff hikes - a trade war. The Trump administration introduced 10 percent tariffs on additional Chinese imports worth $\$ 200$ billion in September, and then increased it to 25 percent in May 2019. China immediately responded with tariffs on US goods worth $\$ 60$ billion and tariff hikes on US goods worth $\$ 36$ billion. President Trump quickly answered by threatening to impose additional tariffs on imports worth $\$ 300$ billion, which China planned to retaliate against. The conflict was further fueled by US concerns that the Chinese government could force domestic companies such as Huawei, the market leader for $5 \mathrm{G}$ technology, to install backdoors for espionage. In May 2019, the Trump administration

* This article has been double-blind peer reviewed.

The authors would like to thank the reviewers for their helpful comments. prohibited US companies from using communication technology that posed a threat to national security and ultimately banned Huawei from acquiring technology from US firms. However, in October, Trump canceled the scheduled tariff hikes due to a prospect of the first two planned deals. In January 2020, the United States and China signed a "phase one" deal that prevented further escalation, but that left most tariffs imposed during the trade war in effect (cf. Bown and Kolb 2020).

Against the backdrop of an American decline, hegemonic stability theory predicts a turnaround from a liberal to a protectionist and from a cooperative to a confrontational trade policy for the declining hegemon. In this work, we closely examine Trump's trade war and the resulting "phase one" deal to determine whether the US trade policy under President Trump can be regarded as a manifestation of the prediction of hegemonic stability theory. Although hegemonic stability theory has been criticized theoretically (e.g., Gowa 1989) and empirically (e.g., McKeown 1983), we show that Trump's rhetoric and actions regarding the trade war with China fits into the pattern associated with a declining hegemon predicted by hegemonic stability theory. Because we do not focus on systematic changes in world trade policy, the analysis should not be misunderstood as a strict empirical test of this theory but rather as a theoretically guided interpretation of the US-Sino trade war. It is supplemented by a critical reflection to disclose the flaws and risks of Trump's understanding of trade, his aggressive negotiation approach, and the bargaining results. Through such analysis, we aim to provide a general assessment of Trump's trade policy and contribute to the debates about the American decline and the rise of China. Whether the Trump administration's actions can really be traced back to systematic changes or solely to its worldview, which reproduces previous ideas about the behavior of a declining hegemon, is not answered.

\section{Previous US trade policy addressing China's rise}

During his campaign and presidency, Trump regularly criticized China's unfair trade practices and complained about previous administrations that allowed China to "rip off" the United Sates. Such criticisms are not entirely unfounded. China's mercantilist 
economic model is based on vast subsidies favoring high-tech industries and state-owned companies, price dumping, intellectual property theft, and forced technology transfer of foreign corporations to Chinese companies. Steel mills, solar panel producers, and shipbuilders received discounted loans, low-cost electric power, or investment from the state; these subsidies granted them an unfair advantage vis-à-vis foreign competitors but resulted in a number of disadvantages as well, such as unprofitable "zombie" firms and inefficiency (e.g., Barwick, Kalouptsidi, and Zahur 2019). Despite China's clear violations of the WTO rules of free trade and market economy, previous administrations did not tackle them seriously. Nevertheless, previous administrations addressed China's unfair trade practices with various individual actions. For example, the Bush administration filed WTO complaints against China on subsidies and price dumping and put China on the priority watch list for intellectual property theft. The Obama administration denied China the status of "market economy," which should have been automatically granted in 2016 according to a strict reading of the WTO accession treaty. The Obama administration even initiated a new strategy of rebalancing, known as the "Pivot to Asia," in 2011. It called for a deep diplomatic, economic, and security engagement with other states in Asia to counterbalance the rise of China (cf. Sutter 2018, 145-47). The TPP - a free trade agreement with several Pacific countries, including Japan, Malaysia, Singapore, and Vietnam - was the economic cornerstone of this strategy. However, both administrations favored a cooperative approach toward China that offered no clear strategy on how to tackle China's unfair trade practices and pressure China to change its economic policies.

Such an appeasing approach toward China is motivated by several factors. First, previous administrations were driven by the misperception that China's opening and integration into the world market would lead to a free-market conforming behavior and democratization in the long run. However, this view turned out to be an illusion. Despite its integration into the world economy, China maintained its mercantilist economic model. Second, the rise of China was not seen as a top priority. The Bush administration was focused on the global war against terrorism, whereas the Obama administration (at the beginning of his presidency) had to handle the aftermath of the financial crises. Third, the political pressure by US companies for such actions was minimal relative to that during the high trade imbalance with Japan in the 1980s. China was more open to foreign imports and investments than Japan back in the 1980s. Furthermore, US companies became transnationalized with international value chains in the course of digitalization. Japanese exports were produced by domestic firms, whereas Chinese exports also came from US companies, such as Nike and Apple. Such US companies had invested in China or at least maintained deals with companies in China to produce or assemble their goods for the American market using global value chains. In addition to such companies, many US producers benefited from cheap Chinese intermediate goods such as steel, and US retailers such as Walmart profited from cheap Chinese consumer goods such as textiles, toys, and electronic products (cf. Irwin 2017; Sutter 2018). Fourth, although Chinese imports cost the US manufacturing sector, specifically the apparel industry, approximately 548,000 jobs from 1990 to 2000 and an additional 982,000 jobs between 2000 and 2007
(Autor, Dorn, and Hanson 2013), these job losses accounted for less than 5 percent of all involuntary job losses during this period. Most job losses in manufacturing were caused by innovation and increased productivity (Hicks and Devaraj 2015). The overall US unemployment rate even dropped between 2002 and 2006 because of the booming housing market. Hence, the job losses caused by trade did not receive much attention in Washington.

Finally, although China's potential as a hegemonic challenger was already apparent before the financial crisis, it was still a long way off. Nevertheless, China's rise became clear and urgent after the financial crisis. It might even explain the Obama administration's "Pivot to Asia" strategy. Since then, the power shift between the United States and China has become a defining feature of US-Sino relations.

\section{American decline and Trump's understanding of trade}

Over the past two decades, China's rise from a developing country to an emerging superpower has been accompanied by an American decline. China challenges the hegemony of the United States in Asia nowadays, and it could potentially do so on a global scale in the near future. China only made 3.6 percent of the global gross domestic product (GDP) in 2000, but this number increased to 15.8 percent in 2018. On the contrary, the US' share of the global GDP decreased from 30.5 percent in 2000 to 23.9 percent in 2018 (World Bank n.d.). During the same period, China's share of world trade (exports and imports) grew from 3.9 percent to 12.5 percent, whereas US exports and imports only accounted for 10.6 percent in 2018 from the previous 15.6 percent in 2000 (World Integrated Trade Solution n.d.). In military terms, China spent $\$ 249.9$ billion in 2018; this value represented a huge jump from its $\$ 22.9$ billion expenditure in 2000. By contrast, the United States increased its military expenditures from $\$ 301.7$ billion to $\$ 648.8$ billion during the same period (World Bank n.d.). Although the US and China can be seen as economic competitors and strategic rivals, both countries have developed an interdependence over the past decades. After China's entry to the WTO in 2001, the US-Sino trade in goods rapidly grew from $\$ 116.2$ billion in 2000 to $\$ 659.2$ billion in 2018; at the same time, the US trade deficit with China rose from $\$ 83.8$ billion in 2000 to $\$ 419.5$ billion in 2018 (U.S. Census Bureau n.d.). Therefore, the US-Sino trade relation is unique not only because of its sheer size and imbalance but also because of the fact that China is the new challenger of American hegemony from the economic, technological, and military aspects.

According to scholars of hegemonic stability theory and neorealism, a hegemon in ascent is interested in facilitating a liberal world order on the basis of free trade. A benevolent hegemon is even willing to bear a great burden to provide international public goods, such as free trade and stability. However, a hegemon in decline becomes interested in protectionism to safeguard its superior status (Krasner 1976; Lake 1990; Gilpin 1981). Even if not explicitly outlined, hegemonic stability theory makes different assumptions depending on a hegemon's status. An ascending hegemon views trade as a 
positive-sum game. As this hegemon can afford possible power losses due to its superior position, it considers the absolute gains of trade in the long run rather than the relative power losses in the short term. Therefore, an ascending hegemon favors the creation of institutions - we could say structural power (Strange 1987) - over the exercise of relational or hard power, although it does not abstain completely from using carrots and sticks. On the contrary, a declining hegemon is concerned about its declining power in relation to other great powers. By fighting a type of rearguard battle, this hegemon tries not to lose its position and shifts from a liberal to a mercantilist perspective. Hence, a declining hegemon views trade as a zero-sum game and tries to prevent power losses by using hard power (cf. Krasner 1976; Gilpin 1981).

Several scholars argue that the reason for a hegemon's decline is the world order created by the hegemon itself. Technological innovation is difficult to create and is expensive, but technology is usually diffused easily, particularly under free trade, and efforts to prevent such diffusion fail in the long term. In addition, the military and economic costs for the hegemon to provide international public goods rise over time when ascending states often challenge the status quo and become free riders. These costs of maintaining the status quo are no longer available to the hegemon for productive investments. Furthermore, the hegemon's private and public consumption may grow faster than its gross national product (cf. Gilpin 1981; see also Eichengreen 1989; Stein 1984). When the hegemon is in decline, the rising power attempts to change the international system in its favor. Therefore, the rising power faces direct conflict with the hegemon, ultimately leading to a hegemonic war (Gilpin 1981; for an overview of the hegemonic stability theory, its developments and criticism see Ikenberry and Nexon 2019).

From this perspective, Trump's trade policy can be understood as an expression of the American decline. His rhetoric mirrors the arguments of the aforementioned hegemony theories. He criticizes the imperial overstretch, emphasizing that the United States must bear high costs to maintain a liberal world order that is not in its national interest. He sees other countries, China in particular, as free riders and rejects the self-image of the United States as a benevolent hegemon. Thus, he clearly breaks away from the US trade policy established after World War II. Since the 1940s, the United States has been pursuing a liberal trade policy and establishing a world order on the basis of free trade. For the establishment of a world order according to the country's ideas, previous US administrations were willing to give more economic concessions than its trading partners (Janusch 2018a 2018; Krasner 1976).

Trump's mercantilist understanding of trade fits the arguments of hegemonic stability theory. Trump assumes free trade as a zero-sum game; the loss of one country is the gain of another. He identifies winners and losers with only one indicator: trade balance. Countries with a trade surplus are winners, whereas countries with a trade deficit get "ripped off" and lose production, jobs, and welfare to their trading partners. Hence, the main objective is to induce economic growth and create jobs by reducing the trade deficit (Janusch and Witold 2017). Trump seems to view trade agreements as transactional contracts to achieve short-term gains, comparable to a real estate business deal, rather than as institutional arrangements to define longterm rules for free trade. By taking this mercantilist view, he deviates from the liberal beliefs of previous administrations that saw trade as a positive-sum game in which all countries profit. As Trump sees China's unfair trade practices as a major cause for the trade deficit, the Trump administration is concerned about China's mercantilist policies - in other words, China's role as a free rider in the liberal world order.

\section{Trump's "maximum pressure" approach}

Trump's mercantilist understanding of trade is also closely linked to, if not the origin of, his confrontational negotiation approach in trade policy. Under a simplified view of trade as a zero-sum game, Trump's argument that a trade war with China "is easy to win" becomes understandable. Under the assumption that a trade deficit is equal to an absolute loss, simply ending all trade relations becomes beneficial. However, Trump does not seem to be an advocate of protectionism per se, which was the case in the 1920s when the United States raised tariffs only to protect its industries (e.g., Smoot-Hawley Tariff Act) with no intention to strike trade deals. Despite his rhetoric, Trump sees tariffs as a bargaining leverage and not as an end in itself, as proven by the negotiated trade deals with Mexico, Canada, and China. Trump always emphasizes his interest in making trade deals. This view and these actions contradict the argument of hegemonic stability theory that protectionist measures are not only a mean but also an end for a declining hegemon; however, one should consider that hegemonic stability theory was developed during a period when international interdependencies were considerably lower. An updated theory that considers today's global value chains might arrive at different conclusions regarding the optimal trade policy for a declining hegemon. Such consideration would supplement newer developments in hegemonic studies to understand hegemons as not only order makers but also order takers whose domestic politics interacts with changes of the international order (Ikenberry and Nexon 2019).

Nevertheless, Trump's negotiation approach fits the notion of hegemonic stability theory that a declining hegemon uses its hard power in an attempt to prevent the rise of other great powers. His "maximum pressure" approach almost exclusively relies on hard power - the imposition or threat of tariffs - and is true to his motto, "Use your leverage" (Trump and Schwartz 1987, 37). By contrast, the Bush and Obama administrations relied on the rule-based WTO dispute settlement rather than on threats to impose tariffs. In addition, the Trump administration prefers unilateral actions or bilateral negotiations instead of multilateral negotiations, because Trump believes that the United States could more effectively use its power in bilateral negotiations than in multilateral ones. Therefore, the negotiation approach of the Trump administration resembles the unilateral "resultoriented" approach of the Reagan administration toward Japan, which, for example, agreed with voluntary export restraints for cars and ended price dumping for semiconductors (see Irwin 2017, ch. 12). 
Trump is convinced that the United States has the greater leverage vis-à-vis China because of its huge trade deficit. This understanding of leverage is based on the notion of asymmetric interdependence, which is also the definition of power in hegemonic stability theory (Krasner 1976). A state that depends less on cooperation than its counterpart has more leverage because it can credibly threaten to abrogate cooperation (Hirschman 1945; Keohane and Nye 2001). Given the large economy and trade imbalance of the United States, Trump's assertion is correct to some extent. The United States remains less dependent than China regarding trade. US exports (total trade) of goods to China account only for 1.1 (3.2) percent of US' GDP, whereas Chinese exports (total trade) to the United States make up 2.8 (4.9) percent of China's GDP (U.S. Census Bureau n.d.). Although a trade deficit is not necessarily damaging for the economy as Trumps assumes, ${ }^{1}$ it still indicates a lower dependency vis-à-vis the trading partner. Finding a seller is usually easier than finding a buyer (Hirschman 1945). However, the numbers also show that the US-Sino trade relation is not as important for both countries as often perceived.

Furthermore, bargaining leverage depends not only on asymmetric interdependence but also on a negotiator's reputation. Trump is aware of this fact. "The worst thing you can possibly do in a deal is seem desperate to make it" (Trump and Schwartz 1987, 37). According to bargaining theory (Satori 2002; Janusch 2018b), negotiators appear weak when they back down from their own threats, in which case future threats lose credibility. Thus, negotiators refuse to back down to prevent such a reputational loss, even when backing down is a good option in the current situation. Moreover, negotiators are willing to suffer short-term losses to increase their reputation for decisiveness and determination in order to gain benefits in the long term. By carrying out threats despite the costs, Trump strengthens his reputation as a resolute negotiator and therefore increases the credibility of his future threats.

Even if the Trump administration's aggressive negotiating style should not be regarded as useless from the outset and China may otherwise never change its unfair trade practices, the "maximum pressure" approach comes with major flaws and risks. The Trump administration overestimates its leverage. Although an asymmetric interdependence in favor of the United States exists in trade, the resulting bargaining leverage is limited and minimal, and its use comes with great costs for both sides, including high consumer prices, reduced competitiveness due to rising input costs, and increasing inefficiencies because of trade diversion. Even if the Trump administration strengthens its reputation by showing resolve, China would also suffer a reputational loss when it gives in to threats (see Sechser 2010); this effect explains why Trump's threats led to a myriad of tariff hikes. By starting trade conflicts with various major trading partners, the Trump administration reduces the chances to achieve major concessions by China. Coordinated action

1 For example, an increasing part of Chinese imports - 26.9 percent in 2000 and 44.5 percent in 2018 (World Integrated Trade Solution n.d.) are capital goods that can increase the competitiveness of the United States in the long run. A trade deficit does not necessarily indicate a country's competitiveness, rather than consumer preference. The current trade deficit is, for most parts, driven by the higher US consumption rate and lower saving rate than those of other countries; see Pearson (April 11, 2017, February 9, 2017). by the United States and the European Union toward China could more likely prompt fundamental changes to China's economic model.

Furthermore, Trump's negotiation approach is based on the wrong indicator of success. Given that Trump measures the success of his trade policy in terms of trade balance, the effect of its punitive tariffs may be misinterpreted. Although tariffs against specific countries can influence bilateral trade imbalance to a certain extent, they lack a significant impact on the overall trade deficit of a country. During the trade war, the US trade deficit with China declined, whereas the trade imbalance with other countries and alliances, such as the European Union, Mexico, and Canada, increased. The US trade deficit can be decreased by reducing the overall US trade, increasing competitiveness, or changing the consumption and saving rate. However, the tax reform and deficit spending during the Trump presidency are doing the opposite, as they increase the trade deficit. Thus, if Trump were to be reelected, then he may be tempted to use punitive tariffs against other countries because of the United States' (apparent) success against China and the rising trade deficit with other countries. However, the upcoming economic crises resulting from the coronavirus pandemic will most likely lead to a reduction of the overall trade and trade deficit.

\section{5. "Phase one" deal: A trade ceasefire}

Despite these flaws, the "maximum pressure" approach still resulted in the so-called "phase one" deal of a planned two-tier agreement. However, to what extent does the "phase one" deal prevent future conflicts between the declining hegemon and its challenger? Can it be seen as rebuttal of hegemonic stability theory? At first glance, the deal addresses the Trump administration's concerns about unfair trade practices and the trade deficit and could thus be regarded as a building block for preventing future conflicts between the declining hegemon and its ascending challenger. First, China agreed to strengthen intellectual property protections, related legal proceedings, and strict measures related to patents, trademarks, and geographical indications to prevent piracy. However, independent from the trade deal, China intended to strengthen its intellectual property rights because Chinese companies have become market leaders in many sectors. Second, China emphasized that it would not require or pressure US companies to transfer their technology in return for having access to its market or receiving licensing and administrative approvals. Third, China agreed to reduce trade barriers related to sanitary and phytosanitary standards for agricultural goods. Fourth, China pledged to open its financial service sectors, such as banking services, asset management, and insurance, to US companies. Fifth, the US and China reaffirmed their commitment under the International Monetary Fund (IMF) not to devalue their currencies to facilitate their exports. Sixth, China pledged to buy additional US goods and services worth $\$ 200$ billion above the 2017 levels for two years (USTR 2020; Politi 2020).

Although the provisions on intellectual property rights and forced technology transfers are good starting points, the "phase 
one" deal is no game changer and comes with major problems. The high tariffs imposed during the trade war have become the new normal with no end in sight for the near future. Although the Trump administration suspended a planned tariff hike on $\$ 160$ billion and cut an existing 15 percent tariff on Chinese goods worth $\$ 100$ billion in half, tariffs covering $\$ 250$ billion in Chinese imports and the sanctions against Huawei were kept in place (Bown 2019). China cut in half the tariffs imposed on $\$ 75$ billion of US goods but retained its other tariffs during the trade war (Xin and Zhou 2020). The imposed tariffs decreased the trade deficit, but they exerted the opposite effect on jobs. The positive effect on import-competing industries was offset by job losses in companies that suffered high input costs and lost export sales due to retaliatory tariffs (Flaaen and Pierce 2019).

Instead of addressing major problems, such as China's subsidies for state-owned enterprises and cyber theft, the "phase one" deal has left China's mercantilist economic model and necessary structural changes for most parts untouched. Furthermore, the goal of the deal to increase Chinese purchases of US goods and services by $\$ 200$ billion entails a rather "result-oriented" approach aimed at reaching certain export targets instead of minimizing trade barriers (except for financial services) and leveling the playing field. Apart from the diverting effects on global trade and resulting inefficiencies, the deal builds a unstable foundation for an enduring trade peace by setting unrealistic purchasing goals that can hardly be matched by China (Bown 2020). In addition, disputes related to the deal can easily result in its termination. According to the agreement, if a dispute cannot be settled after consultations between the US trade representative and China's vice premier, then the complaining party can suspend obligations under the agreement or impose remedial measures, such as tariffs without a counter-response, as long as the action is taken in "good faith." If such an action is considered by the other side to be in "bad faith", then the remedy is withdrawal from the agreement (USTR 2020).

The lack of solutions to structural problems, the unrealistic purchasing goals, and the insufficient conflict resolution will not prevent and may even fuel future conflicts in a growing contentious relation between the declining hegemon and the ascending challenger. Thus, the deal is a trade ceasefire rather than a basis for a stable trade peace. The tensions and blame game between the United States and China as a result of the coronavirus pandemic and the following economic crises further support this assessment. In May 2020, Trump already threatened to terminate the deal if China should not fulfill its commitments. In August, Trump signed an executive order banning Chinese apps like TikTok and WeChat due to national security concerns. Although the Trump administration has not yet cancelled the "phase one" deal, China-bashing has become a central part of the Republicans' and Democrats' campaigns in the upcoming presidential elections. This is also reflected in US public opinion, which increasingly perceives China as a threat. These developments and the aforementioned contractual shortcomings suggest that the "phase one" deal will be not more than a short-term break in a long-term hegemonic trade war, as predicted by hegemonic stability theory; nevertheless, other factors, such as domestic interest groups, could be of importance to prevent such outcome.

\section{Conclusions}

President Trump's understanding of trade and negotiation mirrors the basic arguments made by hegemonic stability theory with regard to a declining hegemon. In contrast to previous presidents, Trump rejects the self-image of the United States as a benevolent hegemon that is willing to maintain the liberal world order while other countries are free riding. Trump's notion about the American decline, his view on trade as a zero-sum game, and his idea of using maximum pressure at all times are the factors driving the trade war of the United States with China. Thus, Trump can be seen as a manifestation that confirms the hypotheses of hegemonic stability theory. However, because the Trump administration is only one piece in the puzzle, one cannot quickly establish whether Trump's approach is a long-term turnaround or simply a short-term anomaly in US trade policy. Although more critical of China, US society still largely supports free trade (Jones 2018), not to mention the large number of US industries with many market leaders depending on global value chains. The new complex structure of the world economy questions whether or not a declining hegemon would favor mercantilist policies, as argued by hegemonic stability theory, which was developed during a period when interdependency was far from its present complexity even if it was already an issue in political science. Instead, globalization suggests that in addition to states, transnational corporations and interdependencies due to global value chains should be considered when applying the hegemonic stability theory.

Although a confrontational approach seems inevitable to bring a rising China to the table for negotiations, the Trump administration's unilateral "maximum pressure" approach has been insufficient to pressure China to reform its mercantilist economic model. The "phase one" deal seems to be a trade ceasefire rather than a lasting peace in the ongoing contentious relations between the United States and China. The tariffs imposed during the trade war are likely the new normal. More important, this ceasefire stands on a shaky foundation because it sets unrealistic goals and is built upon a dispute settlement that favors deal determination over rule-based conflict resolution. Thus, the deal will not prevent and may even fuel further conflicts. Hence, the "phase one" deal would become a short-term break in a long-term hegemonic conflict, as predicted by hegemonic stability theory.

If Trump were to be reelected or if a Democratic candidate were to become the new President, the US-Sino relations will remain contentious and difficult to solve in the future. The resulting uncertainty for businesses will facilitate the decoupling of the two of the world's largest economies, a process that already started during the trade war. Many US companies have started to shift their supply chains to other Asian countries due to their fear of further tariff hikes. If China's rise should continue, then an increasing decoupling and a decreasing interdependence will more likely facilitate future conflicts - not only in trade but also in security affairs - between a declining hegemon and its ascending challenger. 


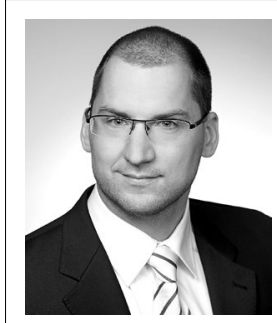

Dr. Holger Janusch is an associate professor in the North American Studies Program at the Rheinische Friedrich-WilhelmsUniversität in Bonn, Germany. His research focus is on US trade politics, international political economy, bargaining theory, and power in international relations theory.

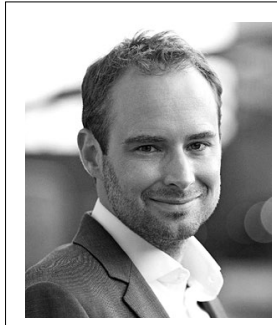

Dr. Daniel Lorberg is a project director of the Solar Decathlon Europe 21 at the Bergische Universität in Wuppertal, Germany. He currently works on digitalization, transnational corporations, sustainability, and global economy.

\section{References}

Autor, David H., David Dorn, and Gordon H. Hanson. 2013، "The China Syndrome: Local Labor Market Effects of Import Competition in the United States." American Economic Review 103 (6): 2121-68.

Barwick, Panle J., Myrto Kalouptsidi, and Nahim B. Zahur. 2019 “China's Industrial Policy: An Empirical Evaluation." NBER Working Paper Series 26075. https://www. nber.org/papers/w26075. Accessed February 15, 2020.

Bown, Chad P. 2019. Phase One China Deal: Steep Tariffs Are the New Normal. Peterson Institute for International Economics, December 19. Accessed February 12, 2020. https://www.piie.com/blogs/trade-and-investment-policy-watch/phase-one-chinadeal-steep-tariffs-are-new-normal.

2020. Unappreciated Hazards of the US-China Phase One Deal. Peterson Institute for International Economics, January 21. Accessed February 12, 2020. https:// www.piie.com/blogs/trade-and-investment-policy-watch/unappreciated-hazardsus-china-phase-one-deal.

Bown, Chad P., and Melina Kolb. 2020. Trump's Trade War Timeline: An Up-to-Date Guide. Peterson Institute for International Economics, January 24 . Accessed February 12, 2020. https://www.piie.com/blogs/trade-investment-policy-watch/trump-tradewar-china-date-guide

Eichengreen, Barry. 1989. "Hegemonic Stability Theories of the International Monetary System." In Can Nations Agree? Issues in International Economic Cooperation, edited by Richard N. Cooper, Barry Eichengreen, Gerald Holtham, Robert D. Putnam, and C. R. Henning, 255-99. Washington: Brookings Institution Press.

Flaaen, Aaron, and Justin Pierce. 2019. Disentangling the Effects of the 2018-2019 Tariffs on a Globally Connected U.S. Manufacturing Sector. inance and Economics Discussion Series, no. 2019-086. Washington: Board of Governors of the Federal Reserve System.

Gilpin, Robert. 1981. War and Change in World Politics. Cambridge: Cambridge University Press.

Gowa, Joanne. 1989. "Rational Hegemons, Excludable Goods, and Small Groups: An Epitaph for Hegemonic Stability Theory?" World Politics 41 (3): 307-24.

Hicks, Michael J., and Srikant Devaraj. 2015. The Myths and Realities of Manufacturing in America. Muncie: Center for Business and Economic Research, Ball State University.

Hirschman, Albert O. 1945. National Power and the Structure of Foreign Trade. Publications of the Bureau of Business and Economic Research University of California. Berkely: University of California Press.

Ikenberry, G. J., and Daniel H. Nexon. 2019. "Hegemony Studies 3.0: The Dynamics of Hegemonic Orders." Security Studies 28 (3): 395-421.

Irwin, Douglas A. 2017. Clashing over Commerce: A History of US Trade Policy. Chicago: University of Chicago Press.

Janusch, Holger. 2018a. "America First und das Ende des wohlwollenden Hegemonen: Handelspolitik unter Präsident Trump." In Angriff auf die liberale Weltordnung, edited by Christopher Daase and Stefan Kroll, 171-90. Wiesbaden: VS Verlag für Sozialwissenschaften.

2018b. "The Interaction Effects of Bargaining Power: Interplay between Veto Power Asymmetric Interdependence, Audience Costs, and Reputation." Negotiation Journal 34 (3): 219-241.

Janusch, Holger, and Mucha Witold. 2017. "America First: Power and Geopolitics in US Trade Policy under President Trump." Security and Peace 35 (3): 110-14.

Jones, Bradley. 2018. Americans Are Generally Positive about Free Trade Agreements, More Critical of Tariff Increases. Pew Research Center, May 10. Accessed March 24, 2020. https://www.pewresearch.org/fact-tank/2018/05/10/americans-are-generally-positiveabout-free-trade-agreements-more-critical-of-tariff-increases/.

Keohane, Robert O., and Joseph S. Nye. 2001. Power and Interdependence. New York: Longman Publishing Group.

Krasner, Stephen D. 1976. "State Power and the Structure of International Trade." World Politics 28 (3): 317-47.
Lake, David A. 1990. Power, Protection, and Free Trade: International Sources of U.S Commercial Strategy, 1887-1939. Ithaca: Cornell University Press.

McKeown, Timothy J. 1983. "Hegemonic Stability Theory and 19th Century Tariff Levels in Europe." International Organization 37 (1): 73-91.

Pearson, Daniel R. 2017a. Au Contraire, Mr. President: Trade Deficit Is Not a Big Deal. Cato Institute, February 9. Accessed April 18, 2017. https://www.cato.org/publications/ commentary/au-contraire-mr-president-trade-deficit-not-big-deal.

. 2017b. Trade Deficit: Ask the Wrong Questions, Get the Wrong Answers. Cato Institute, April 11. Accessed April 18, 2017. https://www.cato.org/publications/ commentary/trade-deficit-ask-wrong-questions-get-wrong-answers.

Politi, James. 2020. "What's in the US-China 'Phase One' Trade Deal?" Financial Times, January 15. Accessed February 12, 2020. https://www.ft.com/content/a01564ba37d5-11ea-a6d3-9a26f8c3cba4.

Satori, Anne E. 2002. "The Might of the Pen: A Reputational Theory of Communication in International Disputes." International Organization 56 (1): 121-49.

Sechser, Todd S. 2010. "Goliath's Curse: Coercive Threats and Asymmetric Power." International Organization 64 (4): 627-60.

Stein, Arthur A. 1984. "The Hegemon's Dilemma: Great Britain, the United States, and the International Economic Order." International Organization 38 (2): 355-86.

Strange, Susan. 1987. "The Persistent Myth of Lost Hegemony." International Organization 41 (4): 551-74.

Sutter, Robert G. 2018. U.S.-China Relations: Perilous Past, Uncertain Present. 3rd edition. Lanham: Rowman \& Littlefield.

Trump, Donald J., and Tony Schwartz. 1987. Trump: The Art of the Deal. New York: Random House.

U.S. Census Bureau. n.d. "Foreign Trade Data: U.S. Trade in Goods by Country." Accessed January 15, 2020. https://www.census.gov/foreign-trade/balance/index.html.

USTR. 2020. Economic and Trade Agreement Between the United States of America and the People's Republic of China. Accessed February 12, 2020. https://ustr.gov/sites/ default/files/files/agreements/phase\%20one\%20agreement/Economic_And_Trade_ Agreement_Between_The_United_States_And_China_Text.pdf.

World Bank. n.d. "World Bank Open Data." Accessed January 15, 2020. https://data worldbank.org/.

World Integrated Trade Solution. n.d. "Database." Accessed January 15, 2020. https:// wits.worldbank.org/WITS/WITS/Restricted/Login.aspx

Xin, Zhou, and Cissy Zhou. 2020 "Trade War: China Announces Tariff Cuts as Part of Phase One Deal Despite Coronavirus Outbreak." South China Morning Post, February 6. Accessed February 12, 2020. https://www.scmp.com/economy/china-economy/ article/3049287/trade-war-china-announces-tariff-cuts-part-phase-one-deal.

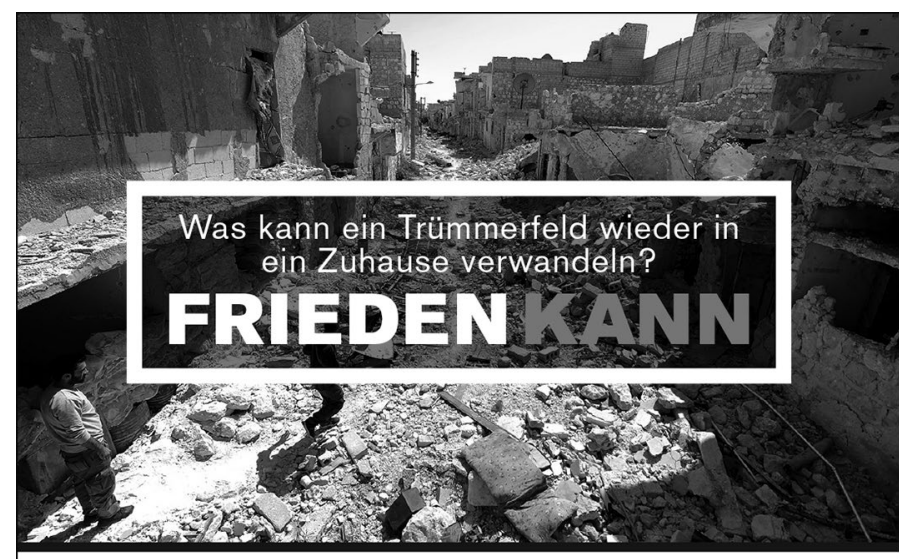

Was kann allen Menschen ein www.ziviler-friedensdienst.org gutes Leben ermöglichen? Frieden kann! Dafür setzt sich der Zivile Friedensdienst (ZFD) seit 20 Jahren erfolgreich ein. Dieses Programm für Friedensförderung und Gewaltprävention stärken heißt, mehr Verantwortung für eine friedliche Welt übernehmen.

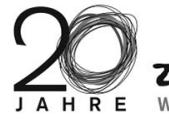
Wir scheuen keine Konflikte. 